\title{
Nuremberg Code
}

National Cancer Institute

\section{Source}

National Cancer Institute. Nuremberg Code. NCI Thesaurus. Code C142617.

A set of ten ethical principles for human experimentation established as a result of the Nuremberg trials at the end of the Second World War. 